\title{
PENGARUH PENAMBAHAN ASAM SITRAT PADA PROSES PEREBUSAN DAN PERENDAMAN KEDELAI UNTUK MEMPERCEPAT PROSES FERMENTASI TEMPE
}

\section{The Effect of Citric Acid Addition in Boiling and Soaking Process of Soybean on Accelerating of Tempe Fermentation}

\author{
Zakki Rosmi Mubarok*, Mohammad Fatwa, Deden \\ Jurusan Teknik Kimia Fakultas Teknik Universitas Pamulang \\ Jalan Surya Kencana No. 1 Pamulang Kota Tangerang Selatan, Banten 15417 \\ Email: zakkirosmimubarok@gmail.com
}

\begin{abstract}
ABSTRAK
Penelitian ini bertujuan untuk mengetahui pengaruh penambahan asam organik dalam proses fermentasi tempe. Asam organik yang digunakan adalah asam sitrat yang diharapkan dapat mempercepat proses hidrolisa baik dimulai dari proses perebusan hingga proses perendaman. Adapun konsentrasi asam sitrat yang ditambahkan adalah 10\% untuk setiap proses. Penambahan asam sitrat pada proses perendaman 4 jam memerlukan waktu fermentasi optimum 21,33 jam dengan penghematan waktu 55,56\%, sedangkan penambahan asam sitrat pada proses perendaman dan perebusan selama 4 jam memiliki waktu fermentasi optimum 21,75 jam dengan penghematan waktu 54,69\%. Selain itu, dilakukan uji kandungan asam sitrat sisa yang terkandung dalam tempe dengan HPLC dan didapatkan nilai $0,1-0,2 \%$.
\end{abstract}

Kata kunci : Kedelai, Tempe, Hidrolisa, Asam Sitrat, Fermentasi

\begin{abstract}
Research's goal of this study is determining some effects on added organic acid from soybean into tempe by fermentation. Acid was used is citric acid to accelerate hydrolytic from boiling into soaking process. The results show that reaching $\mathrm{pH}=4$ need $10 \mathrm{ml} / 100 \mathrm{ml}$ air. Moreover, optimum fermentation needs 21.33 hour for 4 hours soaking process, and 55.56 efficiency time needs 21.33 hour for 4 hours soaking process, and 55.56\% efficiency time. In other hand, optimum fermentation needs 21.75 hour for 4 hours soaking process and boiling process with efficiency time about 54,69\%. Final product is screening by HPLC shows that citric acid residue in tempe is $0.1-0,2 \%$.
\end{abstract}

Keywords : Soybean, Tempe, Hydrolytic, Citric Acid, Fermentation

\section{PENDAHULUAN}

Indonesia merupakan negara tempe terbesar di dunia dan menjadi pasar kedelai terbesar di Asia yaitu sebanyak 50\% dari konsumsi kedelai di Indonesia adalah tempe, $40 \%$ tahu, dan 10\% dalam bentuk produk lain (seperti tauco, kecap dan lainlain). Konsumsi tempe rata-rata per orang per tahun di Indonesia saat ini diduga sekitar 6,45 kg [1].
Tempe merupakan produk fermentasi jamur Rhizopus sp yang sangat dikenal oleh masyarakat Indonesia dan mancanegara [2]. Tempe diminati oleh masyarakat, selain harganya murah, tempe juga memiliki kandungan protein nabati yang tinggi. Setiap $100 \mathrm{~g}$ tempe mengandung $4 \mathrm{~g}$ zat lemak, 18-20 g zat protein, $129 \mathrm{mg}$ zat kalsium dan vitamin B12 [3]. Sedangkan kedelai sebelum diolah menjadi tempe mengandung serat 4,9 g [4]. 
Melalui proses pembuatan tempe, kedelai menjadi lebih enak dimakan dan meningkat nilai nutrisinya karena rasa dan aroma kedelai berubah sama sekali setelah menjadi tempe. Proses pembuatan tempe adalah cara untuk mengubah kedelai agar mudah dicerna dan enak rasanya. Dengan pembuatan tempe, kadar protein yang larut dalam air akan meningkat akibat aktivitas enzim proteolitik. Tempe lebih dapat diterima oleh masyarakat setelah menjadi bahan pangan (dikonsumsi) dibanding masih berupa kedelai. Tempe yang masih baik (baru) memiliki rasa dan bau yang spesifik [5].

Secara umum proses pembuatan tempe dalam perendaman dan perebusan hanya menggunakan air biasa. Hal ini menyebabkan $\mathrm{pH}$ hanya mencapai 6,5 sehingga pada saat fermentasi jamur tempe membutuhkan waktu yang lebih banyak. Suasana asam atau $\mathrm{pH}$ yang sesuai bagi pertumbuhan jamur tempe berkisar antara 4 sampai 5. Dalam penelitian ini digunakan asam sitrat sebagai asam organik untuk mempercepat proses hidolisa kedelai sebelum menjadi tempe. Asam sitrat memiliki kemampuan untuk membuat suasana asam yang sesuai bagi pertumbuhan jamur tempe serta sebagai bahan pengawet yang baik dan alami sehingga dengan perbandingan tertentu berpotensi sebagai aditif (katalisator fermentasi) pada proses perebusan dan perendaman kedelai. Waktu proses perebusan dan perendaman yang optimal dalam proses produksi tempe akan dapat memperkecil biaya produksi tempe (dikarenakan waktu proses jadi lebih terkendali) juga berpengaruh pada tingkat kualitas produk tempe yang dihasilkan.

\section{BAHAN DAN METODE}

Alat. High performance liquid chromatography (HPLC), heater, pH-meter, Cetakan, dan Alat kukus.

Bahan. Kedelai, asam sitrat, sumber nutrisi CNP, ragi tempe, air.

\section{Pembuatan Tempe Konvensional}

Ditimbang kedelai seberat $\pm 1 \mathrm{~kg}$ lalu dicuci bersih kacang kedelai. Direbus kedelai hingga matang.Selanjutnya direndam dalam air selama 8-24 jam. Dipisahkan kedelai dengan air rendaman lalu dicampurkan ragi tempe dan nutrisi CNP dan dicetak dalam wadah. Ditunggu hasil fermentasi selama 48 jam.

\section{Penambahan Asam Sitrat pada Proses Perendaman Kedelai}

Ditimbang kedelai seberat $\pm 1 \mathrm{~kg}$ lalu dicuci bersih kacang kedelai. Direbus kedelai hingga matang.Selanjutnya direndam kedelai selama 2,4,6,8 jam dalam air yang sudah ditambahkan asam sitrat pada kontrol $\mathrm{pH}=4$ selama 2, 4, 6, dan 8 jam. Dipisahkan kedelai dengan air rendaman lalu dicampurkan ragi tempe dan nutrisi CNP dan dicetak dalam wadah. Ditunggu hasil fermentasi.

\section{Penambahan Asam Sitrat Proses Perebusan dan Perendaman Kedelai}

Ditimbang kedelai seberat $\pm 1 \mathrm{~kg}$ lalu dicuci bersih kacang kedelai. Direbus kedelai dalam air yang sudah ditambahkan asam sitrat pada $\mathrm{pH}=4$ hingga kedelai matang. Selanjutnya direndam kedelai selama 2,4,6,8 jam dalam air yang sudah ditambahkan asam sitrat pada kontrol $\mathrm{pH}=$ 4 selama 2, 4, 6, dan 8 jam. Dipisahkan kedelai dengan air rendaman lalu dicampurkan ragi tempe dan nutrisi CNP dan dicetak dalam wadah. Ditunggu hasil fermentasi 


\section{Uji Asam sitrat sisa pada Tempe dengan HPLC}

Tempe yang telah jadi dipotong dadu dan dihaluskan. ditambahkan air denim dan dihomogenkan. diambil air denim yang telah tercampur tersebut dan ukur dengan HPLC dengan kolom C-18.

\section{HASIL DAN PEMBAHASAN}

\section{Pembuatan Tempe Konvensional}

Tempe konvensional tanpa menggunakan penambahan asam sitrat didapatkan data yang ditunjukkan pada tabel 1. Tabel 1 menunjukkan bahwa waktu fermentasi tempe secara konvensional membutuhkan waktu fermentasi 48 jam atau dapat dikatakan 2 hari. Hal ini disebabkan ragi pada tempe membutuhkan waktu yang lama untuk memecah senyawasenyawa kompleks [6] yang ada pada kedelai menjadi senyawa yang lebih sederhana sehingga dibutuhkan percepatan seperti penambahan asam organik.

Pembuatan tempe dengan penambahan asam sitrat

\section{Penambahan asam sitrat pada proses perendaman}

Pada proses perendaman dengan variasi waktu 2, 4, 6, 8 jam didapatkan waktu fermentasi yang lebih cepat jika dibandingkan dengan tempe konvensional yang dapat dilihat pada gambar 1 berikut:

Tabel 1. Kondisi tempe konvensional

\begin{tabular}{|c|c|c|c|}
\hline No & Parameter & Nilai & $\begin{array}{l}\text { Satu- } \\
\text { an }\end{array}$ \\
\hline 1 & pH perebusan & $6,5-7$ & - \\
\hline 2 & $\begin{array}{l}\text { pH perendaman } \\
\text { awal }\end{array}$ & 6,5 & - \\
\hline 4 & $\begin{array}{l}\text { pH perendaman } \\
\text { akhir }\end{array}$ & $4-5$ & - \\
\hline 3 & Waktu fermentasi & 48 & jam \\
\hline
\end{tabular}

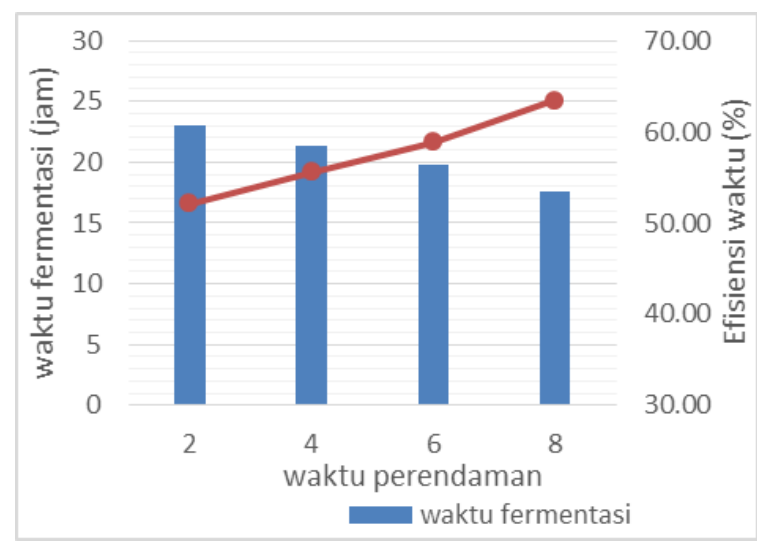

Gambar 1. Pengaruh penambahan asam sitrat pada proses perendaman

Data di atas menunjukkan bahwa perendaman 8 jam (standar dari pembuatan tempe konvensional) didapatkan waktu fermentasi sebesar 17,6 jam sedangkan pada perendaman 2 jam waktu fermentasi adalah 23 jam. Hal ini menjelaskan bahwa penambahan asam organik pada proses perendaman mempengaruhi senyawa kompleks yang terdapat dalam kedelai. Asam sitrat yang terlarut akan menyumbangkan ion $\mathrm{H}^{+}$dalam air dengan nilai $\mathrm{Ka}=7,1 \times 10^{-4}$ dimana:

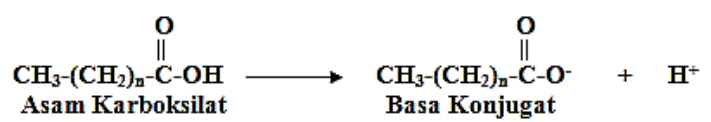

Sehingga mekanismenya:

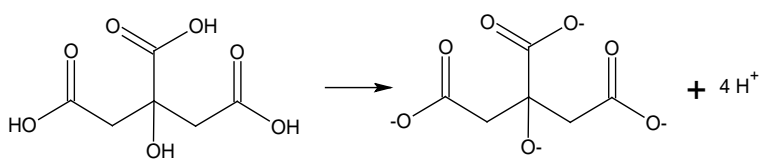

Gambar 2. Ionisasi asam sitrat dalam air

Ion $\mathrm{H}^{+}$yang disumbangkan oleh asam sitrat akan menyerang senyawa kompleks pada kedelai seperti protein menjadi asam amino seperti isoleucine, leusin, lisin, methionine dan lain-lainnya. 


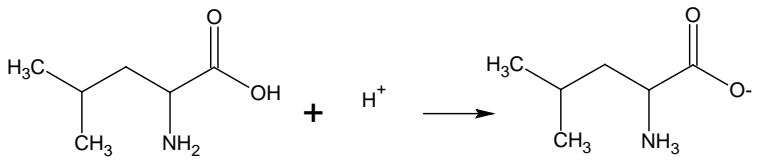

Gambar 3. Penyerangan ion $\mathrm{H}^{+}$pada leusin

Protein yang telah menjadi senyawa yang lebih sederhana akan lebih mudah menjadi sumber nutrisi karbon (C), dan nitrogen (N) bagi ragi tempe untuk dapat hidup (fermentasi) [7].

\section{Penambahan asam sitrat pada proses perendaman dan perebusan}

Pada proses perendaman dengan variasi waktu 2, 4, 6, 8 jam didapatkan waktu fermentasi yang lebih cepat jika dibandingkan dengan tempe konvensional namun masih di bawah nilai pada penambahan asam sitrat di proses perendaman yang dapat dilihat pada gambar 4. Gambar 4 menunjukkan bahwa waktu fermentasi tercepat ada pada perendaman 8 jam sebanyak 17,6 jam sedangkan perendaman 2 jam adalah 24 jam. Proses penambahan asam pada proses perebusan memiliki pengaruh yaitu penurunan waktu fermentasi untuk perendaman 2 dan 4 jam yaitu 1 jam.

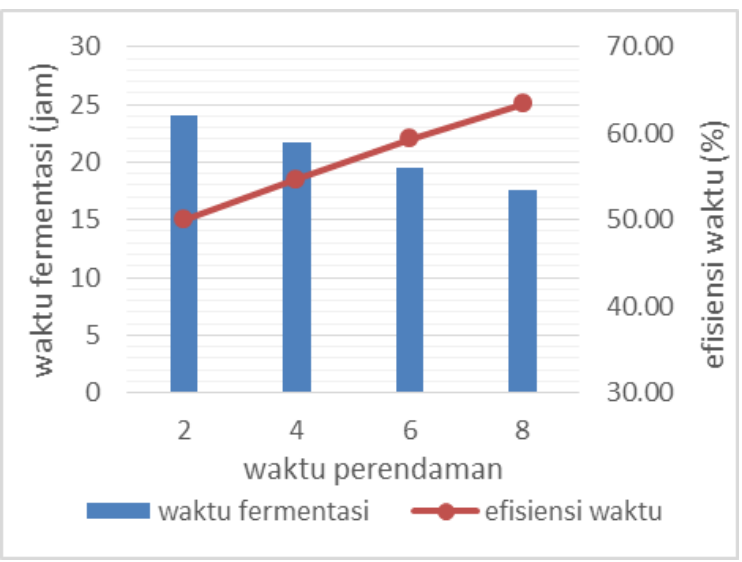

Gambar 4. Pengaruh penambahan asam sitrat pada proses perendaman dan perebusan

\section{Uji kualitas tempe dan total waktu}

Uji kualitas tempe ditunjukkan pada tabel 2. Data di atas dapat dikatakan bahwa waktu perendaman dengan 4 jam memiliki visual, bau, dan warna yang mirip dengan tempe konvensional. Hal ini disebabkan pada perendaman 2 jam, senyawa kompleks dalam tempe belum seluruhnya diubah ke bentuk senyawa sederhana sehingga warna tempe terlihat sedikit berwarna kuning yang merubah kualitas produk (Yustinah, 2014) dan penyebaran ragi di beberapa titik tidak merata. Sedangkan dengan penambahan asam saat perebusan akan mengubah senyawa kompleks berubah menjadi senyawa sederhana sehingga mempercepat proses fermentasi. Namun proses perubahan senyawa ini tidak sebanding dengan jumlah ragi yang menyebabkan kualitas fisik tempe menurun.Dengan kata lain, perlakuan tempe dengan penambahan asam sitrat yang paling optimum ada pada penambahan asam sitrat pada proses perendaman dengan menghasilkan waktu fermentasi 21,33 jam dengan penghematan waktu 55,56\% yang jika dibandingkan dengan penambahan asam sitrat pada proses perebusan dan perendaman dengan menghasilkan waktu fermentasi 21,75 jam dengan penghematan waktu 54,69\%. Selain itu, penambahan asam sitrat juga dapat meningkatkan kualitas nilai pangan [9].

\section{Uji Asam Sitrat Sisa pada Tempe}

Perlakuan terbaik pada penelitian ini ada pada proses perendaman yang kemudian dilakukan uji asam sitrat sisa pada tempe. Adapun hasil pembacaan HPLC ditunjukkan pada pada gambar 5. 
Tabel 2. Uji Kualitas Tempe

\begin{tabular}{|c|c|c|c|c|c|c|c|c|}
\hline \multirow{3}{*}{ Parameter } & \multicolumn{8}{|c|}{ waktu perendaman } \\
\hline & \multicolumn{2}{|c|}{2} & \multicolumn{2}{|c|}{4} & \multicolumn{2}{|c|}{6} & \multicolumn{2}{|c|}{8} \\
\hline & A & $\mathrm{B}$ & A & B & A & B & A & $\mathrm{B}$ \\
\hline $\begin{array}{c}\text { Tebal tempe } \\
\text { Penvebaran hasil }\end{array}$ & +++ & ++++ & ++++ & ++++ & ++++ & ++++ & +++ & +++ \\
\hline Ragi Tempe & ++ & +++ & ++++ & ++++ & +++ & +++ & +++ & +++ \\
\hline warna tempe & ++ & ++ & ++++ & ++++ & +++ & +++ & ++ & ++ \\
\hline Bau Tempe & ++ & ++ & ++++ & ++++ & +++ & +++ & ++ & ++ \\
\hline
\end{tabular}

Tabel 3. Waktu total

\begin{tabular}{ccccc}
\hline Perlakuan (proses) & $\begin{array}{c}\text { Waktu } \\
\text { perebusan } \\
\text { (jam) }\end{array}$ & $\begin{array}{c}\text { Waktu } \\
\text { Perendaman } \\
\text { (jam) }\end{array}$ & $\begin{array}{c}\text { Waktu } \\
\text { fermentasi } \\
\text { (jam) }\end{array}$ & $\begin{array}{c}\text { Total waktu } \\
\text { keseluruhan } \\
\text { (jam) }\end{array}$ \\
\hline Perendaman & 2 & 4 & 21,33 & 27,33 \\
Perebusan+Perendaman & 2 & 4 & 21,75 & 27,75 \\
Konvensional & 2 & 8 & 48,00 & 58,00 \\
\hline
\end{tabular}

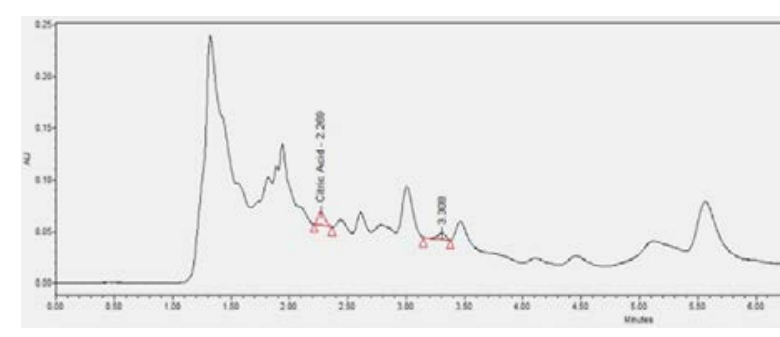

Gambar 5. Hasil uji asam sitrat sisa pada tempe

Gambar 5 menunjukkan bahwa tempe yang telah ditambahkan asam sitrat $10 \%$ memiliki asam sitrat sisa pada peak 2,269 dengan waktu retensi 2,269 menit dengan konsentrasi $\quad 0,11 \%-0,2 \%$. Hal ini menandakan bahwa asam sitrat yang digunakan dalam proses adalah 98,9\% (perubahan dari $10 \%$ menjadi 0,11\%). Dengan kata lain asam sitrat yang terkandung adalah 0,11-0,20\% masih dalam kategori aman (standar WHO 0,3\%). (Budiasih, 2009)

\section{KESIMPULAN}

Dari beberapa data dapat disimpulkan bahwa penambahan asam sitrat pada proses perendaman 4 jam memerlukan waktu fermentasi optimum 21,33 jam dengan penghematan waktu 55,56\%, sedangkan penambahan asam sitrat pada proses perendaman dan perebusan selama 4 jam memiliki waktu fermentasi optimum 21,75 jam dengan penghematan waktu 54,69\%. Uji kandungan asam sitrat sisa yang dengan HPLC didapatkan nilai konsentrasi sebesar 0,1-0,2\%.

\section{DAFTAR PUSTAKA}

[1] Astawan,M.(2004). Tetap Sehat dengan Produk Makanan Olahan. Solo: Tiga Serangkai

[2] Susanto,B. (1994). Teknologi Pengolahan Hasil Pertanian, Surabaya: PT.Bina Ilmu.

[3] Tarwotjo,C.S.(1998). Dasar-dasar Gizi Kuliner, Jakarta:Grasindo

[4] Sulistijani D.(1999).Sehat Dengan Menu Berserat,Jakarta:Trubus Agriwidya.

[5] Kasmidjo,R.B.(1990).Tempe:

Mikrobiologi dan Biokimia Pengolahan 
serta Pemanfaatannya, Yogyakarta:

Universitas Gadjah Mada.

[6] Sarwono. (2005). Membuat Tempe dan Oncom. Jakarta: Penebar Swadaya

[7] Yurliasni, Zakaria Y.(2013). Kajian Penambahan Khamir Kluyveromyces Lactis, Candida Curiosa dan Brettamonyces Custersii Asal Dadih terhadap konsentrasi Asam-Asam Amino, Lemak, Organik dan Karbohidrat Susu Kerbau Fermentasi (Dadih). Jurusan Peternakan. Fakultas Pertanian. Universitas Syiah Kuala Aceh

[8] Yustinah, Rosdiana. (2014). Pengaruh Konsentrasi Asam Sitrat terhadap
Penurunan Bilangan Asam dan Kepekatan Warna Minyak Jelantah Melalui Proses Adsorpsi. Jurusan Teknik Kimia. Fakultas Teknik. UMJ.

[9] Arfiani Aulia S, Febriar Cahyaratri. (2016). Pemanfaatan Asam Sitrat Sebagai Adsorben Dalam Upaya Peningkatan Kualitas Minyak Goreng Bekas Melalui Proses Adsorpsi. Jurusan Teknik Kimia. Fakultas Teknik. Universitas Diponegoro.

.[10] Budiasih, Kun Sri. (2009). Studi Bioanorganik : Mineral Runutan dalam Metabolisme Tubuh. Jurdik Kimia FMIPA UNY. Fakultas MIPA, Universitas Negeri Yogyakarta 